\title{
Nye kriterier for revmatoid artritt
}

\author{
Bakgrunnen for de nye kriteriene for revmatoid artritt er et ønske om tidlig diagnose og behandling \\ for å unngå utvikling av varige skader. I kriteriene har man satt søkelyset på biomarkører som kan være \\ til stede tidlig i sykdomsforløpet. Ved mistanke om revmatoid artritt hos en pasient skal legen umiddelbart \\ henvise til spesialist.
}

\section{Cathrin Nikolaisen}

cathrin.nikolaisen@unn.no

Revmatologisk avdeling

Institutt for klinisk medisin

Universitetet i Tromsø

\section{Emilio Besada}

Revmatologisk avdeling

Universitetssykehuset Nord-Norge

\section{Johannes C. Nossent}

Revmatologisk avdeling

Institutt for klinisk medisin

Universitetet i Tromsø

og

Revmatologisk avdeling

Universitetssykehuset Nord-Norge

Revmatoid artritt er en kronisk, progredierende betennelsessykdom i små og store ledd av ukjent årsak. Den medfører smerte, hevelse og redusert bevegelighet i ledd, etter hvert med varig brusk- og beinskade. Revmatoid artritt affiserer $0,5-1 \%$ av befolkningen, og kvinner affiseres oftere enn menn. Typisk debut er gradvis tiltakende plager.

Klassifikasjonskriterier skiller seg fra diagnostiske kriterier ved at de er ment for forskning hvor man ønsker en homogen sykdomsgruppe. Klassifikasjonskriterier

\section{Ramme 1}

Klassifikasjonskriterier for revmatoid artritt fra 1987 (1).

Fire av sju kriterier måtte oppfylles. De fire første punktene måtte ha vart $>6$ uker

- Morgenstivhet $\mathrm{i}$ ledd $>1 \mathrm{t}$

- Synovitter i håndledd, MCP- eller PIP-ledd

- Symmetriske synovitter

- Synovitter $i \geq 3$ leddområder

- Positiv revmatoid faktor

Revmatisk(e) knute(r)

- Erosive forandringer $\mathrm{i}$ hånd eller håndledd påvist på røntgen definerer dermed et «klassisk» sykdomsbilde. Det finnes ikke egne diagnostiske kriterier for revmatoid artritt. Erfaring viser at klassifikasjonskriterier gjerne blir brukt som diagnostiske kriterier i den kliniske hverdagen, men de brukes da ikke så strengt som ved forskning.

\section{De gamle kriteriene}

De forrige klassifikasjonskriteriene for revmatoid artritt ble vedtatt i 1987 (ramme 1)

(1). De ble utformet av den amerikanske revmatologiske foreningen (American College of Rheumatology, ACR), som tok utgangspunkt i funn hos pasienter som hadde hatt revmatoid artritt i 7,7 år.

Kriteriene inneholdt sju punkter, hvor kravet til klassifisering som revmatoid artritt, var at minst fire kriterier var oppfylt. For de fire øverste kriteriene var kravet at de måtte ha vart i minimum seks uker. Kriteriene revmatiske knuter og erosive forandringer i hender/håndledd oppstår oftest sent i forløpet. Revmatiske knuter oppstår hos en tredel av pasientene og gjenspeiler at sykdommen er blitt ekstraartikulær, dvs. at den angriper andre organer enn ledd, og uttrykker økt alvorlighetsgrad (2).

Kronisk leddbetennelse kan lede til intraartikulær ødeleggelse av bein (erosjoner), som igjen medfører irreversibel skade av ledd. På diagnosetidspunktet påvises erosjoner ved røntgen hos kun få pasienter. Ett år etter diagnose ble erosjoner og avsmalning av leddspalten påvist $\mathrm{i}$ hender hos $2 \%$ og i føtter hos $6 \%$. Etter seks år hadde $95 \%$ av pasientene utviklet erosjoner og avsmalning av leddspalten (3).

Biomarkøren revmatoid faktor (RF) har vært med i kriteriene for revmatoid artritt siden 1956. En biomarkør er en biokjemisk substans som, når den er til stede i blod i unormal mengde, kan indikere forekomst av sykdom og/eller alvorlighetsgrad av sykdommen. Revmatoid faktor ble først beskrevet av bergenseren Erik Waaler (1903-97) i 1940, som «en agglutinerende faktor i sera fra RA-pasienter» (4). Faktoren forekommer ved en rekke andre revmatologiske sykdommer, ved infeksjoner, lungefibrose, primær biliær cirrhose og kreft. Funn av revmatoid faktor øker med alderen og finnes hos opptil $25 \%$ av mennesker over 70 år som ikke har revmatoid artritt. Revmatoid faktor defineres nå som antistoffer som binder Fc-delen av IgG og eksisterer i immunglobulinklassene IgG, IgA, IgE og den klassiske IgM. Forekomst av revmatoid faktor er påvist hele 22 år før symptomstart hos pasienter med revmatoid artritt, med økning i titer over tid før diagnosen stilles (5).

\section{De nye kriteriene}

Arbeidsgrupper fra den amerikanske revmatologiske foreningen og det europeiske forbundet mot revmatisme (The European League Against Rheumatism, EULAR) har utviklet nye klassifikasjonskriterier $(6,7)$. De har tatt utgangspunkt i over 3000 pasienter med udifferensiert artritt med sykdomsvarighet 1-7 måneder.

Utgangspunktet for bruk av kriteriene er at revmatolog finner intraartikulær betennelse (synovitt) i minst ett ledd som vanligvis ikke er utsatt for artrose eller urinsyregikt, og at systemisk lupus erythematosus (SLE) og psoriasis ikke foreligger. Videre vurderes varighet av symptomer, antall og størrelse på ledd med synovitt, aktuell autoimmun serologi og akuttfasereaktanter (tab 1). Punktene vektlegges med forskjellige skårer, og diagnosen revmatoid artritt foreligger ved poengsum $\geq 6$. Ti er maksimal poengsum.

\section{Sammenlikning}

Kriteriet om symptomvarighet på seks uker er med både i de gamle og nye kriteriene, men det er nytt at pasienter med synovitt av kortere varighet kan inkluderes dersom de oppnår minst seks poeng.

Begge kriteriesettene forutsetter eksklusjon av andre sykdommer som kan forklare synovitt. Punktene om morgenstivhet, revmatiske knuter og erosive forandringer er fjernet. Morgenstivhet er fjernet, trolig fordi det er et symptom som opptrer ved mange ulike sykdommer. De to sistnevnte forandringene kommer sent i forløpet av revmatoid artritt og er utelatt siden man i de nye kriteriene vektlegger tidlig diagnostikk.

Et skille mellom synovitt i store og små ledd er innført, mens kriteriene om at minst 
tre leddområder skal ha synovitt, og symmetrisk forekomst av synovitt, er fjernet. I de gamle kriteriene rettet man søkelyset mot synovitt $\mathrm{i}$ hender, mens man nå inkluderer ledd i hele kroppen, inklusive temporomandibular-, akromioklavikulær- og sternoklavikulærleddene som tidligere ikke ble inkludert. Skulder- og hofteleddene er også inkludert - siden artritt kan påvises her ved ultralydundersøkelse og regnes sammen med albuer, knær og ankler som store ledd. Av små ledd er håndledd, IPledd i tomler, PIP-, MCP- og 2.-5. MTPledd inkludert. Ny versjon ekskluderer synovitt i 1 . MTP-ledd (urinsyregikt) og alle DIP- og 1. CMC-ledd (psoriasisartritt og artrose).

\section{Serologiske prøver}

Resultater for senkningsreaksjon (SR), C-reaktivt protein (CRP), revmatoid faktor (RF) og anti-citrullinert peptid-antistoff (ACPA) er tatt med i de nye klassifikasjonskriteriene. Økt søkelys på de to sistnevnte biomarkørene passer med at sykdommen er autoimmun og at autoantistoff(er) kan utvikles lenge før kliniske symptomer og funn oppstår.

Senkningsreaksjon, som ble introdusert i 1918 av svenske Robin Fåhreus (1888-1968), er en enkel og billig test som gjenspeiler effekten av fibrinogen på sammenklumping av erytrocytter. Senkning kan betraktes som en treg del av akuttfaseresponsen, og påvirkes bl.a. av kjønn, alder, svangerskap og sykdommer som medfører økt fibrinogen og immunglobuliner, inkludert høy titer av revmatoid faktor.

C-reaktivt protein ble første gang beskrevet i 1930 (8) og er det første beskrevne akuttfaseprotein. Ved binding til mikrobe gjenkjennes C-reaktivt protein av C1q som aktiverer den klassiske komplementvei. C-reaktivt protein er uavhengig av autoantistoffer som kan gi falskt positiv senkning, men kan påvirkes av overvekt (9). Analysen er lett tilgjengelig og billig, og internasjonal standardisering finnes.

Anti-citrullinert peptid-antistoff, først påvist i 1964 som perinukleær faktor, dannes når peptider blir citrullinert i synovialt vev (10). Ved citrullinering endres aminosyren arginin til citrulline, og peptidet endrer struktur og funksjon. Anticitrullinert peptid-antistoff kan forekomme 14 år før diagnosen revmatoid artritt (11), men det foreligger ikke bevis for stigende titerverdi frem mot diagnosen (12). Analysemetoden for anti-citrullinert peptidantistoff er til en viss grad standardisert.

I de nye kriteriene legger man stor vekt på titer av serologiske biomarkører. Kraftig forhøyet RF- og/eller ACPA-nivå (i.e. større enn tre ganger øvre normalverdi ved lokalt laboratorium) gis hele tre poeng, dvs. halvparten av poengsummen som er nødvendig for diagnosen.

Tabell 1 Klassifikasjonskriterier for tidlig revmatoid artritt fra 2010 (6, 7). Forutsetning for bruk av kriteriene er funn av minst ett ledd med synovitt som ikke kan forklares med annen sykdom. Poengsum fra A til $D$ legges sammen. Ved poengsum $\geq 6$ har pasienten revmatoid artritt

\section{A Ledd med synovitt}

1 stort ledd

$2-10$ store ledd

1-3 små ledd (med eller uten involverte store ledd)

4-10 små ledd (med eller uten involverte store ledd)

10 ledd (minst ett lite ledd)

\section{B Serologiske prøver (minst ett testresultat er nødvendig)}

Negativ revmatoid faktor og negativt anti-citrullinert peptid-antistoff

Revmatoid faktor eller anti-citrullinert peptid-antistoff forhøyet mellom én og tre ganger øvre normalverdi

Revmatoid faktor eller anti-citrullinert peptid-antistoff forhøyet mer enn tre ganger øvre normalverdi

C Akuttfasereaktanter (minst ett testresultat er nødvendig)

Normal senkningsreaksjon og normalt C-reaktivt protein

Forhøyet senkningsreaksjon eller forhøyet C-reaktivt protein

D Varighet av symptomer

$<6$ uker

$\geq 6$ uker

Store ledd: skulder, albue, hofte, kne og ankel

Små ledd: MCP-, PIP-, 2.-5. MTP-ledd, IP-ledd i tomler og håndledd. Ledd med synovitt som ikke nevnes spesielt, for eksempel temporomandibular-, akromioklavikulær- og sternoklavikulærledd, kan inkluderes som små ledd

Alle DIP-, 1. CMC- og 1. MTP-ledd ekskluderes ettersom synovitt her kan knyttes til psoriasisartritt, artrose og urinsyregikt

\section{Vurdering}

De gamle klassifikasjonskriteriene var 23 år gamle. Mye ny kunnskap om diagnostikk og behandling har kommet $\mathrm{i}$ disse årene og er implementert i de nye kriteriene. Søkelyset er nå rettet mot tidlig diagnostikk og målrettet behandling med ønske om å forebygge skadeutvikling og bedre pasientenes prognose.

En svakhet ved de nye kriteriene er at man har basert seg på pasienter med udifferensiert artritt hvor revmatolog har ment at behandling med metotreksat var indisert. Dette har ekskludert en del pasienter som har fått behandling med salazopyrin eller antimalariamidler (som sannsynlig har en lettere form for revmatoid artritt) eller kombinasjonsterapi (som sannsynlig har en mer alvorlig revmatoid artritt). Inklusjon av disse pasientene, som utgjør rundt $20 \%$ av alle nye pasienter med revmatoid artritt, ville endret både spesifisitet og sensitivitet for de nye kriteriene.

Biomarkøren revmatoid faktor er fremdeles med i kriteriene - til tross for at den er meget uspesifikk. Begrunnelsen er at ikke alle land har tilgang til ACPA-testing. I de nye kriteriene spesifiserer man heller ikke hvilken av de mange tilgjengelige metodene som skal brukes ved RF-analyse. Det er oppsiktsvekkende at analysemetoden for revmatoid faktor i løpet av 50 år ikke er blitt standardisert, ikke engang i Norge. Flere har uttrykt skepsis til at høy titerverdi av revmatoid faktor skal være med i kriteriene - ettersom studier viser at dette ikke kan predikere utvikling av revmatoid artritt fra udifferensiert artritt (13).

Teoretisk sett kan revmatoid faktor peke mot en annen etiologi enn anti-citrullinert peptid-antistoff ved revmatoid artritt siden patogenesen til sykdommen per i dag ikke er kjent, men den praktiske nytteverdien av RF-testing er lav. Ved valg av kun én «leddgiktsprøve», bør valget falle på anti-citrullinert peptid-antistoff som har bedre spesifisitet og lik sensitivitet som IgM-RF for tidlig revmatoid artritt (11). Slik praksis er blitt gjennomført ved Universitetssykehuset Nord-Norge siden 2008, hvor RF-test nå kun er tilgjengelig i spesielle tilfeller. Dette har medført reduksjon i arbeid og kostnader knyttet til RF-testing.

Akuttfasereaktantenes senkningsreaksjon og C-reaktivt protein var med i kriteriene for revmatoid artritt fra 1958 som ett av seks kriterier for sykdommen «mulig revmatoid artritt». De ble ekskludert ved senere revisjoner pga. lav sensitivitet og spesifisitet. De er begge uttrykk for inflammasjon, og C-reaktivt protein påviser dette og akutt vevskade mer presist enn senkningsreaksjon (14). Forhøyet verdi av begge ses også ved andre revmatologiske sykdommer. C-reaktivt protein og senkningsreaksjon tilhører de biomarkørene som kan være til stede i tidlig fase av revmatoid artritt. Økt C-reaktivt protein og/ eller senkningsreaksjon får kun ett poeng 
i de nye kriteriene - i motsetning til at flere poeng gis ved forekomst av biomarkørene revmatoid faktor/anti-citrullinert peptidantistoff og/eller flere synovitter.

Økt bruk av biomarkører blant fastleger vil trolig føre til flere henvisninger av pasienter med positive biomarkørsvar og få kliniske funn. Dette fordrer at revmatologer utvikler «tidlig artritt-poliklinikker» for å kunne fange opp pasienter med revmatoid artritt så tidlig som mulig. Det vil medvirke til rask oppstart av målrettet behandling for å motvirke kroniske forandringer hos dem som har fått diagnosen.

En fare ved ukritisk bruk av kriterier er at man kan inkludere pasienter med annen sykdom. For eksempel vil en pasient med synovitt $\mathrm{i}$ høyre hånds 2 . MCP-ledd med varighet $i$ ett år og forhøyet CRP- og RFresultat få to poeng for synovitt i 2 . MCPledd, som er et lite ledd, tre poeng for sin mye forhøyede revmatoide faktor og ett poeng for forhøyet C-reaktivt protein. På denne måten får pasienten totalt seks poeng og skal ha diagnosen revmatoid artritt etter de nye kriteriene. Klinisk erfaring taler for at pasienten ikke har revmatoid artritt siden han/hun kun har hatt affeksjon i ett ledd i løpet av ett år. Ved bruk av de gamle kriteriene oppfyller pasienten bare kravet om artritt $\mathrm{i}$ hånd og får ikke diagnosen revmatoid artritt. Eksemplet illustrerer at det fremdeles er en spesialistoppgave å stille denne diagnosen.

\section{Konklusjon}

For fastleger som finner uforklarlig synovitt hos en pasient, og som mistenker revmatoid artritt, vil de nye klassifikasjonskriteriene rettferdiggjøre rekvisisjon av biomarkører og rask henvisning til revmatolog. Henvisningen til revmatolog kan gjerne skrives før prøvesvarene foreligger. Klinisk under- søkelse og vurdering av revmatolog er viktig både for tidlig å stille korrekt diagnose og for tidlig å begynne med sykdomsmodifiserende behandling.

\section{Cathrin Nikolaisen (f. 1968)}

er førsteamanuensis ved revmatologisk avdeling ved Universitetet i Troms $\varnothing$. Hun har ph.d. om revmatoid artritt og biomarkører. Oppgitte interessekonflikter: Forfatteren har mottatt honorar for foredrag fra Pfizer i 2010.

\section{Emilio Besada (f. 1971)}

er assistentlege ved revmatologisk avdeling ved Universitetssykehuset Nord-Norge. Ingen oppgitte interessekonflikter.

\section{Johannes C. Nossent (f. 1955)}

er spesialist i indremedisin og revmatologi med spesiell interesse for autoantistoffer ved systemiske autoimmune sykdommer. Han er overlege ved Universitetssykehuset Nord-Norge og professor ved Universitetet i Troms $\varnothing$, hvor han leder forskergruppen Ben og ledd ved Institutt for klinisk medisin. Han er også leder for Fagrådet i Norsk Revmatologisk Forening. Oppgitte interessekonflikter: Forfatteren har mottatt honorar for foredrag fra Phadia.

\section{Litteratur}

1. Arnett FC, Edworthy SM, Bloch DA et al. The American Rheumatism Association 1987 revised criteria for the classification of rheumatoid arthritis. Arthritis Rheum 1988; 31: 315-24.

2. Turesson C, O'Fallon WM, Crowson CS et al. Extra-articular disease manifestations in rheumatoid arthritis: incidence trends and risk factors over 46 years. Ann Rheum Dis 2003; 62: 722-7.

3. Hulsmans HM, Jacobs JW, van der Heijde DM et al. The course of radiologic damage during the first six years of rheumatoid arthritis. Arthritis Rheum 2000; 43: 1927-40.

4. Waaler E. On the occurrence of a factor in human serum activating the specific agglutination of sheep blood corpuscles. Acta Pathol Microbiol Scand 1940; 17: 172-88.

5. Rantapää-Dahlqvist S, de Jong BA, Berglin E et al Antibodies against cyclic citrullinated peptide and IgA rheumatoid factor predict the development of rheumatoid arthritis. Arthritis Rheum 2003; 48 : 2741-9.

6. Aletaha D, Neogi T, Silman AJ et al. 2010 rheumatoid arthritis classification criteria: an American College of Rheumatology/European League Against Rheumatism collaborative initiative. Ann Rheum Dis 2010; 69: 1580-8.

7. Aletaha D, Neogi T, Silman AJ et al. 2010 Rheumatoid arthritis classification criteria: an American College of Rheumatology/European League Against Rheumatism collaborative initiative. Arthritis Rheum 2010; 62: 2569-81.

8. Tillett WS, Francis T. Serological reactions in pneumonia with a non-protein somatic fraction of pneumococcus. J Exp Med 1930; 52: 561-71.

9. Visser M, Bouter LM, McQuillan GM et al. Elevated C-reactive protein levels in overweight and obese adults. JAMA 1999: 282: $2131-5$.

10. Schellekens GA, de Jong BA, van den Hoogen FH et al. Citrulline is an essential constituent of antigenic determinants recognized by rheumatoid arthritis-specific autoantibodies. J Clin Invest 1998; 101: 273-81.

11. Aggarwal R, Liao K, Nair R et al. Anti-citrullinated peptide antibody assays and their role in the diagnosis of rheumatoid arthritis. Arthritis Rheum 2009: 61: 1472-83.

12. Neogi T, Aletaha D, Silman AJ et al; American College of Rheumatology; European League Against Rheumatism. The 2010 American College of Rheumatology/European League Against Rheumatism classification criteria for rheumatoid arthritis: Phase 2 methodological report. Arthritis Rheum 2010; 62: 2582-91

13. van der Linden MP, Batstra MR, Bakker-Jonges LE et al; Foundation for Quality Medical Laboratory Diagnostics. Toward a data-driven evaluation of the 2010 American College of Rheumatology/ European League Against Rheumatism criteria for rheumatoid arthritis: is it sensible to look at levels of rheumatoid factor? Arthritis Rheum 2011; 63 : 1190-9.

14. Pepys MB, Hirschfield GM. C-reactive protein: a critical update. J Clin Invest 2003; 111: 1805-12.

Mottatt 24.5. 2011, første revisjon innsendt 21.6. 2011, godkjent 3.11. 2011. Medisinsk redaktør Mette Sagsveen. 